Doi: HTTPS://DOI.ORG/10.23910/IJBSM/2017.8.2.1607a

\title{
Influence of Mulching and Weed Management Practices on Weeds and Nutrient Uptake in Greengram (Vigna rediata L.) under Eight Year Old Custard Apple Plantation
}

\author{
S. K. Verma ${ }^{1^{*}}$, S. K. Prasad ${ }^{1}$, S. B. Singh ${ }^{2}$, Y. V. Singh ${ }^{3}$, Ravi Prakash Singh ${ }^{4}$ and Shiv Bahadur ${ }^{5}$ \\ 1,4,5 Dept. of Agronomy, ${ }^{3}$ Dept. of Soil Science and Agricultural Chemistry, Institute of Agricultural Sciences, BHU, Varanasi, \\ U.P. (221 005), India \\ ${ }^{2}$ Dept. of Agronomy, G.B. Pant University of Agriculture and Technology, Pantnagar, Uttrakhand (263 145), India
}

\section{Corresponding Author}

S. K. Verma

e-mail: suniliari@gmail.com

\author{
Article History \\ Manuscript No. AR1607a \\ Received in $3^{\text {rd June, }} 2017$ \\ Received in revised form 23 $3^{\text {rd }}$ March, 2017 \\ Accepted in final form $5^{\text {th }}$ April, 2017
}

\begin{abstract}
An experiment was conducted at Agronomy Research Station, Barkacha, Mirjapur 201-14 to assess the effect of mulching and weed management practices on weeds and nutrients uptake by greengram under agri-horti system. Three mulch treatments were taken in main plot (no-mulching, dust-mulching and paddy straw-mulching) and five weed control treatments (weedy check, weed free, pendimethalin

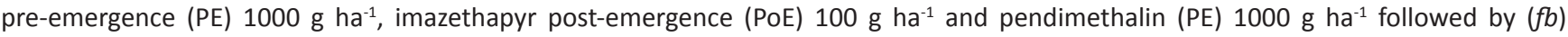
imazethapyr (PoE) $100 \mathrm{~g} \mathrm{ha}^{-1}$ ) was randomly allocated to subplots and these were replicated thrice in split plot design. The results revealed that dust mulching recorded lowest density and dry weight of weeds, N, P, K depletion by weeds and resulted significantly the highest growth parameters (pant height, crop dry weight and branches palnt ${ }^{-1}$ ), N, P, K content and their uptake by crop, grain and straw yield, gross and net returns of greengram over paddy straw mulching and no-mulching, respectively. Pre-emergence application of pendimethalin $\left(1000 \mathrm{~g} \mathrm{ha}^{-1}\right) \mathrm{fb}$ post-emergence application of imazethapyr $\left(100 \mathrm{~g} \mathrm{ha}^{-1}\right)$ recorded lowest density and dry weight of weeds, N, $\mathrm{P}, \mathrm{K}$ depletion by weeds and recorded the highest growth parameters, grain and straw yield, N, P, K contents and their uptake, gross and net returns by crop as compared to alone application of pendimethalin (PE) $1000 \mathrm{~g} \mathrm{ha}^{-1}$ and imazethapyr (PoE) $100 \mathrm{~g} \mathrm{ha}^{-1}$, respectively. However, no mulching recorded maximum B: $\mathrm{C}$ ratio in among the mulches and among weed management practices alone application of pendimethalin recorded maximum $\mathrm{B}: \mathrm{C}$ ratio.
\end{abstract}

Keywords: Herbicides, mulching, nutrient content, nutrients uptake, weed, yield

\section{Introduction}

Greengram (Vigna radiata L.) is one of the most widely cultivated pulse crops in the country and is grown on about $3.44 \mathrm{mha}$ with the annual production of $1.78 \mathrm{mt}$ along with the productivity of $499 \mathrm{~kg} \mathrm{ha}^{-1}$ (DES, 2013). Greengram grown in different seasons and cropping systems due to its wider adoptability and less sensitivity to photoperiod and thermal variations. The conventional rainy season crop is affected due to aberrant weather conditions and its greater vulnerability to weeds (Mitra and Bhattacharya, 2005) and other insect-pests and diseases. Growth behaviour of this crop differs in different seasons due to variation in temperature, photoperiod, humidity etc. (Dodwadiya and Sharma, 2012). Its initial growth rate is relatively slow and consequently weeds have a smothering effect on crop plants and compete for growth resources (Verma et al., 2008). Mulching reduce evaporation, soil erosion, increasing infiltration and population of microorganisms, improve soil moisture status, nutrient utilization, soil temperature regulation and can suppress weeds, due to delayed emergence and smothering effect on weeds (Sharma and Singh, 2010; Manhas et al., 2011). Applications of 10 tons of rice or wheat straw as mulch in greengram reduce emergence and growth of weeds and have a favourable effect on yield (Verma et al., 2008). Moreover, straw mulch can add a fair amount of nutrients and improve the physicochemical properties of the soil. By virtue of being a restorer of soil fertility, pulses have a unique position in the cropping system, particularly in dry land or rainfed agriculture (Khanda et al., 2005). Agri-horti system markedly increases the returns per unit of land mainly during early stage of horticultural fruit trees. The relatively short juvenile (pre-production) phase of fruit trees, high market value of products and the contribution of fruits to household dietary needs, fruit-tree-based agro forestry enjoy high popularity among producers worldwide. In Vindhyan region of Uttar Pradesh growing of pulses, intercropped with custard apple, guava, bael, subabool, and Kronda etc., are more suitable under the agri-hortil system. 
Greengram is a viable option as an intercrop in the alleys of agri-horticultural plantation which provides extra income and also improves the soil fertility (Muthiah, 2004).

It is a short duration crop needs more attention on weed control. Weeds grow more vigorously and pose as serious threat to its cultivation. Being a rainy season crop, it is heavily infested by a large number of fast growing weeds, especially during the critical period of crop-weed competition. Thus, reduces the yield of greengram by $42-64 \%$. Often $2-3$ hand weeding is required to keep the greengram weed free but manual weeding is costly, time consuming and labour intensive also (Singh et al., 2014). However, its additional advantage of providing greater aeration and soil moisture conservation cannot be ignored. But, with the increasing crisis of labour, exploring the possibility of herbicidal weed control in greengram deserves attention. Now a day's herbicide is an integral part of intensive agriculture throughout the world. Herbicide not only save valuable time and money but also allow large coverage in short period of time. Greater knowledge of compatible agro-forestry species greatly facilitates formulation of agroforestry systems with higher yields. Simultaneously, influence of weed management practices on weeds and crops would generate a better understanding to improve cropweed competition. However, the information on comparative performance of mulching and weed management practices on weeds and nutrients uptake by greengram under agri-horti system is lacking. Keeping above facts in mind the present investigation was carried out to study the effect of mulching and weed management practices on weed and nutrients uptake by greengram under agri-horti system.

\section{Materials and Methods}

A field study was conducted during the kharif seasons of 2013-14 at south campus, Institute of Agricultural Sciences, $\mathrm{BHU}$, Varanasi, Uttar Pradesh. The experimental site is located at $85^{\circ} \mathrm{E}$ longitude and $25^{\circ} \mathrm{N}$ latitude and at an altitude of $365 \mathrm{~m}$ MSL. The experimental soil was sandy clay loam with $\mathrm{pH}$ 6.2. The soil was low in available $\mathrm{N} 176.2 \mathrm{~kg} \mathrm{ha}^{-1}$, medium in available P (11.2 $\left.\mathrm{kg} \mathrm{ha}^{-1}\right)$ and available K (184.5 kg ha-1). Field capacity $(7.9 \%)$, permanent wilting point $(1.8 \%)$ and bulk density $\left(1.53 \mathrm{Mg} \mathrm{m}^{-3}\right.$ ) were recorded in $0-30 \mathrm{~cm}$ soil depth. The experiment was laid out in a split plot design using three mulch treatments viz., $M_{1}$-no mulch, $M_{2}$-dust mulch (manipulation of soil with Khurpi (Spud) after the occurrence of rainfall when soil condition is appropriate) and $\mathrm{M}_{3}$ - paddy straw mulch $\left(6^{\text {th }} a^{-1}\right.$ after the emergence of crop plant at $7^{\text {th }}$ day) were assigned as main-plots, whereas five weed control treatments viz., $\mathrm{W}_{1}$-weedy check, $\mathrm{W}_{2}$-weed free ( $\mathrm{HW}$ at 20 and $40 \mathrm{DAS}), \mathrm{W}_{3}$ - pendimethalin pre-emergence (PE) $1000 \mathrm{~g}$ $\mathrm{ha}^{-1}, \mathrm{~W}_{4}$-imazethapyr post-emergence (PoE) $100 \mathrm{~g} \mathrm{ha}^{-1}$ and $\mathrm{W}_{5}-$ pendimethalin (PE) $1000 \mathrm{~g} \mathrm{ha}^{-1}$ followed by $(f b)$ imazethapyr (PoE) $100 \mathrm{~g} \mathrm{ha}^{-1}$ was randomly allocated to subplots and replicated thrice. The greengram 'HUM-16' was sown on $19^{\text {th }}$ July 2013 with the help of manual single row drill at $30.0 \mathrm{~cm}$ row spacing using $20 \mathrm{~kg}$ seed ha-1 in $4.0 \times 4.5 \mathrm{~m}^{2}$ gross plot size under the eight year old custard apple (Annona squamosa L.) plantation. Custard apple is one of the delicious and nutritious fruits can be grown in areas with rainfall as low as $400 \mathrm{~mm}$. It was probably introduced into Australia from British Guiana. It is erect, with a rounded or spreading crown and trunk 10 to 14 inches $(25-35 \mathrm{~cm})$ thick. Height of the tree ranges from 15 to 35 feet $(4.5-10 \mathrm{~m})$ which is at a spacing of $5 \times 5 \mathrm{~m}^{2}$. Fertilizer was applied 20-60-40 NPK kg ha-1 in the form of urea, single super phosphate and murate of potash, respectively. All the nitrogen, phosphorous and potash were applied at the time of sowing. Herbicides was applied in respective treatment combinations with the help of flat fan nozzle attached to the foot sprayer using volume of spray $500 \mathrm{I} \mathrm{ha}^{-1}$. All agronomic and cultural operations were followed for the success the crop. Data on density and dry weight of weed was recorded at 90 DAS from an area enclosed in the quadrate of $0.25 \mathrm{~m}^{-2}$ randomly selected at three places in each plot. Oven dry weight of weeds was recorded at $70^{\circ} \mathrm{C}$ for $48 \mathrm{hr}$. and expressed as dry matter $\mathrm{g} \mathrm{m}^{-2}$. The crop plants from each net plot were harvested on $18^{\text {th }}$ September 2013 separately and stacked plot wise for sun drying and subsequent threshing. Weed and crop samples were analyzed for nutrient concentration as per the standard procedure. N, P and K uptake $\left(\mathrm{kg} \mathrm{ha}^{-1}\right)$ were calculated by multiplying their nutrient (NPK) concentration with weed biomass and crop yield. Data recorded on various observations analyzed statistically as per the standard analysis of variance to draw valid conclusions.

\section{Results and Discussion}

\subsection{Density and dry weight of weed}

All the mulching and weed management treatments significantly reduced the density and dry weight of weeds as compared to no-mulching and weedy check (Table 1). Dust mulching recorded significantly the lowest density and dry weight of weeds over paddy straw mulching. Similar results are also reported by Verma et al. (2016). Sometimes some weeds emerged even after the application of herbicides also, but due to the breaking of soil surface (Dust mulching) after each irrigation or rainfall events weed seedling gets uprooted and die-off and straw mulching also successfully restricts weed emergence (Verma et al., 2016). Density and dry weight reflected the growth potential of the weed and its competitive ability with crop plants. Weedy check recorded the highest density and dry weight of weeds while it was lowest under weed free (HW at 20 and 40 DAS). Among the herbicidal treatments, sequential application of pendimethalin (1000 $\mathrm{g} \mathrm{ha}^{-1}$, pre-em) fb imazethapyr (100 $\mathrm{g} \mathrm{ha}^{-1}$, post-em) recorded lowest density and dry weight of weeds followed by the alone application of pendimethalin (1000 $\mathrm{g} \mathrm{ha}^{-1}$, pre-em) and imazethapyr (100 $\mathrm{g} \mathrm{ha}^{-1}$ post-em), respectively. Lower weed density and dry matter accumulation of weeds under pendimethalin followed by imazethapyr was due to fact that pendimethalin controlled the germination of initial flushes of weeds and imazethapyr controlled weeds emerged at later stages of crop growth. Higher weed control and long lasting effects of pendimethalin and imazethapyr in reducing density and weed dry matter might be primarily due to broad- 


\begin{tabular}{|c|c|c|c|c|c|c|c|}
\hline Treatment & $\begin{array}{l}\text { Weed } \\
\text { density } \\
\left(\mathrm{m}^{-2}\right)\end{array}$ & $\begin{array}{l}\text { Weed dry } \\
\text { weight }(g \\
\left.m^{-2}\right)\end{array}$ & $\begin{array}{l}\text { Plant } \\
\text { height } \\
(\mathrm{cm})\end{array}$ & $\begin{array}{l}\text { Crop dry } \\
\text { weight (g } \\
\text { plant }^{-1} \text { ) }\end{array}$ & $\begin{array}{l}\text { Branch- } \\
\text { es } \\
\text { plant }^{-1}\end{array}$ & $\begin{array}{c}\text { Grain } \\
\text { yield (kg } \\
\left.\mathrm{ha}^{-1}\right)\end{array}$ & $\begin{array}{c}\text { Straw } \\
\text { yield }(\mathrm{kg} \\
\left.\mathrm{ha}^{-1}\right)\end{array}$ \\
\hline \multicolumn{8}{|l|}{ Mulching } \\
\hline No mulching & 101.60 & 9.90 & 35.47 & 7.40 & 3.98 & 597.33 & 15.97.33 \\
\hline Dust mulching & 26.67 & 2.81 & 39.56 & 11.62 & 5.38 & 746.67 & 1796.67 \\
\hline Paddy straw mulching & 67.47 & 6.61 & 37.30 & 9.46 & 4.52 & 711.87 & 1661.87 \\
\hline SEm \pm & 3.99 & 0.69 & 0.17 & 0.05 & 0.35 & 4.30 & 4.32 \\
\hline $\mathrm{CD}(p=0.05)$ & 11.9 & 2.10 & 0.55 & 0.15 & 1.02 & 12.92 & 12.92 \\
\hline \multicolumn{8}{|l|}{ Weed management practices } \\
\hline Weedy check & 140.44 & 13.21 & 34.01 & 9.33 & 3.60 & 602.78 & 1602.78 \\
\hline Weed free (HW at 20 and 40 DAS) & 0.00 & 0.00 & 41.87 & 11.06 & 5.71 & 757.56 & 1757.56 \\
\hline Pendimethalin $1000 \mathrm{~g} \mathrm{ha}^{-1}$ & 62.67 & 6.59 & 36.69 & 10.17 & 4.52 & 689.44 & 1689.44 \\
\hline Imazethapyr $100 \mathrm{~g} \mathrm{ha}^{-1}$ & 79.56 & 7.86 & 35.37 & 9.68 & 4.11 & 650.56 & 1650.56 \\
\hline Pendimethalin $1000 \mathrm{~g}+$ imazethapyr $100 \mathrm{~g} \mathrm{ha}^{-1}$ & 43.56 & 4.52 & 39.28 & 10.55 & 5.18 & 726.11 & 1726.11 \\
\hline SEm \pm & 3.16 & 0.52 & 0.22 & 0.04 & 0.17 & 2.79 & 2.76 \\
\hline $\mathrm{CD}(p=0.05)$ & 9.50 & 1.53 & 0.66 & 0.13 & 0.54 & 8.34 & 8.34 \\
\hline
\end{tabular}

spectrum activity of these herbicides (Verma et al., 2016). Likewise, Gupta et al. (2012) and Singh et al. (2014) also recommended use of imazethapyr in legumes which inhibit acetohydroxy acid synthase and the synthesis of branched chain amino acid in weeds.

\subsection{Nutrients contents in weeds}

The highest nutrients (NPK) content in weeds were recorded under dust mulching as compared to rice straw mulching (Table 2). The lowest weed dry matter accumulation and the maximum moisture availability under dust mulching mainly leads to highest nutrient accumulation in weeds. The nutrients content in weeds increased with the application of herbicides as compared to weedy check. Lowest nutrients content in weeds under no-mulching was due to the highest partitioning of nutrients. The highest nutrient content in weeds was observed under pendimethalin $\mathrm{fb}$ imazethapyr treated plot followed by the alone application of pendimethalin and imazethapyr, respectively. This may be due to lowest density and dry weight of weed, which reduces the partitioning of nutrients. Results are corroborated with the results of Verma et al. (2016)

\subsection{Nutrients depletion by weeds}

The nutrients depletion by weeds increased with increasing the dry matter accumulation by weeds and significantly the highest depletion of nutrients by weeds was recorded under rice straw mulching as compared to dust mulching (Table 3 ). It could be attributed to the maximum dry weight of weeds under rice straw mulching, which helped in maximum accumulation of nutrients by weeds (Verma et al., 2008 and Verma et al., 2016). Herbicidal treatments significantly influenced on the nutrients depletion by weeds. It was significantly the highest under alone application of imazethapyr followed by pendimethalin. The increase in the depletion of nutrients by weeds under this treatment was due to poor control of weeds resulted highest dry weight of weed, which corroborated with the findings of Singh et al. (2014).

\subsection{Crop growth}

Dust mulching recorded significantly tallest plant, highest dry matter accumulation and maximum branches plant ${ }^{-1}$ as compared rice straw mulching and no-mulching, respectively (Table 1). This might be due to fact that the repeated interculture operation for dust mulching obtain weed free situation which provides adequate moisture availability and facilitated nutrient uptake by crop resulted better growth and development as compared to other treatments. Similar results also reported by Verma et al. (2016). Among the herbicidal treatments, sequential application of pendimethalin followed by imazethapyr recorded significantly the tallest plant, highest dry matter accumulation and branches plant ${ }^{-1}$ as compared to the alone application of pendimethalin and imazethapyr, respectively. Results are in close conformity with the findings of Singh et al. (2014).

\subsection{Nutrients content in grain and straw}

The highest nutrients content in grains and straw were recorded under dust mulching as compared to rice straw mulching (Table 2). The lowest weed dry matter accumulation and the maximum moisture availability under dust mulching mainly leads to highest nutrient accumulation in grains and straw. Among herbicidal treatments, highest nutrient content in grain and straw was observed under sequential application of pendimethalin $f b$ imazethapyr treated plot as compared to the alone application of pendimethalin and imazethapyr, 


\begin{tabular}{|c|c|c|c|c|c|c|c|c|c|c|c|c|}
\hline \multirow{2}{*}{\multicolumn{3}{|c|}{ Treatment }} & \multicolumn{4}{|c|}{$\begin{array}{l}\text { Nutrient content in } \\
\text { weeds (\%) }\end{array}$} & \multicolumn{3}{|c|}{$\begin{array}{l}\text { Nutrient content in } \\
\text { grain (\%) }\end{array}$} & \multicolumn{3}{|c|}{$\begin{array}{l}\text { Nutrient content in } \\
\text { straw }(\%)\end{array}$} \\
\hline & & & \multicolumn{2}{|c|}{$\mathrm{N}$} & $\mathrm{P}$ & \multirow[t]{2}{*}{ K } & \multirow[t]{2}{*}{$\mathrm{N}$} & \multirow[t]{2}{*}{$P$} & \multirow[t]{2}{*}{ K } & \multirow[t]{2}{*}{$\mathrm{N}$} & \multirow[t]{2}{*}{$P$} & \multirow[t]{2}{*}{ K } \\
\hline \multicolumn{6}{|l|}{ Mulching } & & & & & & & \\
\hline \multicolumn{3}{|l|}{ No mulching } & \multicolumn{2}{|c|}{1.48} & 0.19 & 2.03 & 3.15 & 0.32 & 1.02 & 1.03 & 0.18 & 2.16 \\
\hline \multicolumn{3}{|l|}{ Dust mulching } & \multicolumn{2}{|c|}{1.58} & 0.22 & 2.22 & 3.30 & 0.35 & 1.06 & 1.11 & 0.21 & 2.22 \\
\hline \multicolumn{3}{|l|}{ Paddy straw mulching } & \multicolumn{2}{|c|}{1.54} & 0.21 & 2.19 & 3.23 & 0.33 & 1.03 & 1.06 & 0.20 & 2.17 \\
\hline SEm \pm & & & 0.0 & 07 & 02 & 0.08 & 0.05 & 0.01 & 0.02 & 0.02 & 0.01 & 0.03 \\
\hline $\mathrm{CD}(p=0.05)$ & & & 0.2 & 20 & 05 & 0.24 & 0.14 & 0.03 & 0.05 & 0.06 & 0.04 & 0.09 \\
\hline Weed management practices & & & & & & & & & & & & \\
\hline Weedy check & & & 1.4 & 42 & 19 & 2.10 & 3.19 & 0.32 & 1.01 & 1.05 & 0.17 & 2.09 \\
\hline Weed free ( $\mathrm{HW}$ at 20 and 40 & & & 1.6 & 66 & 23 & 2.19 & 3.31 & 0.35 & 1.06 & 1.09 & 0.23 & 2.27 \\
\hline Pendimethalin $1000 \mathrm{~g} \mathrm{ha}^{-1}$ & & & 1.5 & 51 & 20 & 2.14 & 3.21 & 0.34 & 1.03 & 1.07 & 0.19 & 2.19 \\
\hline Imazethapyr $100 \mathrm{~g} \mathrm{ha}^{-1}$ & & & 1.4 & 45 & 19 & 2.13 & 3.20 & 0.33 & 1.02 & 1.05 & 0.19 & 2.17 \\
\hline Pendimethalin $1000 \mathrm{~g}+$ imazet & apyr 10 & $0 \mathrm{~g} \mathrm{ha}^{-1}$ & 1.6 & 61 & 22 & 2.16 & 3.22 & 0.34 & 1.05 & 1.08 & 0.21 & 2.21 \\
\hline SEm \pm & & & 0.0 & 04 & 01 & 0.04 & 0.04 & 0.01 & 0.01 & 0.02 & 0.01 & 0.03 \\
\hline $\mathrm{CD}(p=0.05)$ & & & 0.1 & 13 & 04 & 0.13 & NS & NS & NS & NS & NS & NS \\
\hline Table & & 10 & ent pr & tic & grai & in str & ind bio & ologic & ield & ree & & \\
\hline Treatment & $\begin{array}{l}\text { Nutrie } \\
\text { by we }\end{array}$ & $\begin{array}{l}\text { nt depl } \\
\text { eds (kg }\end{array}$ & $\begin{array}{l}\text { etion } \\
\mathrm{ha}^{-1} \text { ) }\end{array}$ & $\begin{array}{r}\text { Nutrie } \\
\text { grai }\end{array}$ & $\begin{array}{l}\text { int upta } \\
\text { in }(\mathrm{kg} \mathrm{h}\end{array}$ & $\begin{array}{l}\text { ake by } \\
\left(a^{-1}\right)\end{array}$ & $\begin{array}{r}\text { Nutrie } \\
\text { stro }\end{array}$ & $\begin{array}{l}\text { ent upta } \\
\text { aw kg ha }\end{array}$ & $\begin{array}{l}\text { ke by } \\
\left.a^{-1}\right)\end{array}$ & $\begin{array}{r}\text { Total } \\
\text { by }\end{array}$ & $\begin{array}{l}\text { utrient } \\
\text { rop }(\mathrm{kg}\end{array}$ & $\begin{array}{l}\text { uptake } \\
\text { ha }^{-1} \text { ) }\end{array}$ \\
\hline & $\mathrm{N}$ & $P$ & K & $\mathrm{N}$ & $P$ & K & $\mathrm{N}$ & $P$ & K & $\mathrm{N}$ & $P$ & K \\
\hline Mulching & & & & & & & & & & & & \\
\hline No mulching & 1.37 & 0.17 & 1.98 & 18.81 & 1.94 & 6.09 & 16.49 & 2.94 & 34.6 & 35.3 & 4.89 & 40.7 \\
\hline Dust mulching & 0.43 & 0.05 & 0.61 & 26.38 & 2.77 & 8.43 & 19.93 & 3.83 & 40.0 & 46.3 & 6.61 & 48.5 \\
\hline Paddy straw mulching & 1.00 & 0.14 & 1.44 & 21.36 & 2.20 & 6.81 & 17.68 & 3.36 & 36.1 & 39.0 & 5.57 & 42.9 \\
\hline SEm \pm & 0.08 & 0.01 & 0.08 & 0.44 & 0.06 & 0.12 & 0.38 & 0.23 & 0.78 & 0.72 & 0.24 & 0.82 \\
\hline $\mathrm{CD}(p=0.05)$ & 0.25 & 0.03 & 0.28 & 1.36 & 0.19 & 0.35 & 1.17 & 0.69 & 2.32 & 2.18 & 0.75 & 2.50 \\
\hline Weed management practices & & & & & & & & & & & & \\
\hline Weedy check & 1.75 & 0.24 & 2.75 & 19.22 & 1.94 & 6.13 & 16.76 & 2.77 & 33.5 & 35.9 & 4.71 & 39.6 \\
\hline $\begin{array}{l}\text { Weed free (HW at } 20 \text { and } 40 \\
\text { DAS) }\end{array}$ & 0.00 & 0.00 & 0.00 & 25.21 & 2.65 & 8.06 & 19.27 & 4.00 & 40.0 & 44.5 & 6.64 & 48.1 \\
\hline Pendimethalin $1000 \mathrm{~g} \mathrm{ha}^{-1}$ & 1.01 & 0.13 & 1.38 & 22.15 & 2.32 & 7.08 & 18.01 & 3.30 & 36.9 & 40.2 & 5.62 & 44.1 \\
\hline Imazethapyr $100 \mathrm{~g} \mathrm{ha}^{-1}$ & 1.16 & 0.14 & 1.63 & 20.87 & 2.17 & 6.65 & 17.35 & 3.21 & 35.8 & 38.2 & 5.37 & 42.4 \\
\hline $\begin{array}{l}\text { Pendimethalin } 1000 \\
\text { g+imazethapyr } 100 \mathrm{~g} \mathrm{ha}^{-1}\end{array}$ & 1.16 & 0.10 & 0.97 & 23.46 & 2.46 & 7.63 & 18.78 & 3.63 & 38.1 & 42.2 & 6.09 & 45.8 \\
\hline SEm \pm & 0.06 & 0.01 & 0.08 & 0.37 & 0.04 & 0.08 & 0.34 & 0.20 & 0.54 & 0.72 & 0.25 & 0.60 \\
\hline $\mathrm{CD}(p=0.05)$ & 0.17 & 0.03 & 0.24 & 1.15 & 0.15 & 0.26 & 1.04 & 0.62 & 1.66 & 2.18 & 0.74 & 1.84 \\
\hline
\end{tabular}

respectively. Results are close conformity with the research findings of Verma et al. (2016).

3.6. Yield and nutrient uptake

Among mulching, dust mulching recorded significantly highest grain and straw yield and nutrients uptake as compared to rice straw mulching. Higher yield and nutrient uptake under dust mulching was due to lowest dry weight of weeds and the better growth and development of crop. Among the weed control treatments, significantly highest yield and nutrients 
uptake was found under weed free treatment and lowest in control plot. A sequential application of pendimethalin followed by $(f b)$ imazethapyr recorded significantly the highest yield and nutrients uptake over alone application of pendimethalin and imazethapyr. This was due to effective control of weeds resulting into better crop growth, yield and nutrients uptake. Results are corroborated with the results of Singh et al. (2014) and Verma et al. (2016).

\subsection{Economics}

Dust mulching gave highest gross and net returns followed by paddy straw mulching and no mulching, respectively (Table 4). Among herbicidal treatments, sequential application of pendimethalin followed by $(f b)$ imazethapyr recorded highest

Table 4: Effect of mulching and weed management practices on economics of greengram

\begin{tabular}{|c|c|c|c|c|}
\hline Treatment & $\begin{array}{c}\text { Total } \\
\text { cost } \\
\left(\mathrm{g} \mathrm{ha}^{-1}\right)\end{array}$ & $\begin{array}{l}\text { Gross } \\
\text { return } \\
\left(\mathrm{g} \mathrm{ha}^{-1}\right)\end{array}$ & $\begin{array}{l}\text { Net } \\
\text { return } \\
\left(\mathrm{g} \mathrm{ha}^{-1}\right)\end{array}$ & $\begin{array}{l}\mathrm{B}: \mathrm{C} \\
\text { ratio }\end{array}$ \\
\hline \multicolumn{5}{|l|}{ Mulches } \\
\hline No mulching & 20186 & 91662 & 71477 & 3.55 \\
\hline Dust mulching & 24058 & 104887 & 80830 & 3.36 \\
\hline Paddy straw mulching & 27126 & 101635 & 74509 & 2.75 \\
\hline \multicolumn{5}{|l|}{$\begin{array}{l}\text { Weed management } \\
\text { practices }\end{array}$} \\
\hline Weedy check & 22344 & 94071 & 71727 & 3.26 \\
\hline $\begin{array}{l}\text { Weed free (HW at } 20 \\
\text { and } 40 \text { DAS) }\end{array}$ & 26224 & 105236 & 79012 & 3.04 \\
\hline $\begin{array}{l}\text { Pendimethalin (PE) } \\
1000 \mathrm{~g} \mathrm{ha}^{-1}\end{array}$ & 23242 & 99012 & 75769 & 3.30 \\
\hline $\begin{array}{l}\text { Imazethapyr (PoE) } 100 \\
\mathrm{~g} \mathrm{ha}^{-1}\end{array}$ & 23114 & 97102 & 73989 & 3.24 \\
\hline $\begin{array}{l}\text { Pendimethalin (PE) } 1000 \\
\mathrm{~g} \mathrm{ha}^{-1}+\text { Imazethapyr } \\
(\mathrm{PoE}) 100 \mathrm{~g} \mathrm{ha}^{-1}\end{array}$ & 24026 & 101555 & 77529 & 3.26 \\
\hline
\end{tabular}

gross and net returns as compared to pendimethalin and imazethapyr, respectively. None of the herbicidal treatments reach to the level of weed free situation with respect to gross and net returns. Maximum gross and net returns were under weed free condition is the result of highest grain and straw yield of greengram. However, no mulching recorded maximum $B$ : $C$ ratio in among the mulches and alone application of pendimethalin recorded maximum $\mathrm{B}: \mathrm{C}$ ratio as compared to other weed management treatments. Similar result were also reported by Verma et al. (2008); Idnani and Gautam (2008).

\section{Conclusion}

Dust mulching and sequential application of pendimethalin followed by $(f b)$ imazethapyr recorded significantly the lowest density and dry weight of weeds and the highest grain and straw yield, nutrients uptake and net returns over alone application of pendimethalin and imazethapyr.

\section{References}

DES, 2013. (Directorate of Economics and Statistics). Department of agriculture and cooperation ministry of agriculture, New Delhi.

Dodwadiya, K.S., Sharma, A.R., 2012. Effect of tillage and method of sowing on performance of greengram varieties during summer and rainy seasons. Indian Journal of Agricultural Sciences 82(5), 462-465.

Gupta, V., Singh, B.N., Kumar, J., Singh, M., Jamwal, B.S., 2012. Effect of imazethapyr on weed control and yield in chickpea under kandi belt of low altitude sub-tropical zone of Jammu. Madras Agriculture Journal 99(1\&3), 81-86.

Idnani, L.K., Gautam, H.K., 2008. Water economization in summer greengram as influenced by irrigation regimes and land configurations. Indian Journal of Agricultural Sciences 78(3), 214-219.

Khanda, C.M., Mandal, B.K., Garnayak, L.M., 2005. Effect of integrated nutrient management on nutrient uptake and yield of component crops in rice based cropping systems. Indian Journal of Agronomy 50(1), 1-5.

Manhas, S.S., Gill, B.S., Khajuria, Kumar, S., 2011. Effect of planting material, mulch and FYM on weeds and yield of Turmeric. Indian Journal of Agronomy 56(4), 393-399.

Mitra, S., Bhattacharya, B.K., 2005. Water use and productivity of greengram as influenced by

spacing, Mulching and weed control under upland situation of Tirpura. Indian Journal of Agricultural Sciences 75(1), 52-54.

Muthiah, A.R., 2004. Opportunities for the cultivation of extra short duration mungbean in Tamil Nadu, India. Proc. Final workshop and planning meeting of 'improving income and nutrition by incorporating mungbean in cereal fallows in the Indo-Gangetic plains of South Asia'. DFID Mungbean Project for 2002-2004'. 27-31 May. PAU, Ludhiana, 183-88.

Sharma, S.N., Singh, R.K., 2010. Weed management in ricewheat cropping system under conservation tillage. Indian Journal of Weed Science 42(1\&2), 23-29.

Singh, G., Aggarwal, N., Ram, H., 2014. Efficacy of postemergence herbicide imazethapyr for weed management in different mungbean cultivar. Indian Journal of Agricultural Sciences 84(4), 540-543.

Verma, S.K., Singh, S.B., Rai, O.P., Singh, G., 2008. Effect of mulching and irrigation on weeds and yield of summer greengram in saline soil. Indian Journal of Agricultural Sciences 78(12), 1082-1085.

Verma, S.K., Kumar, R., Singh, S.B., Meena, R.S., Prasad, S.K., Gaurav, 2016. Weed dynamics in greengram as influenced by mulching and weed management practices under eight ear old Custard apple plantation in agri-horticultural system. American Journal of Experimental Agriculture 11(3), 1-13. 